CLINICAL STUDY

\title{
Wnt receptors, bone mass, and fractures: gene-wide association analysis of LRP5 and LRPG polymorphisms with replication
}

\author{
José A Riancho, José M Olmos, Begoña Pineda ${ }^{1}$, Carmen García-Ibarbia, María I Pérez-Núñez ${ }^{2}$, Daniel N Nan, \\ Javier Velasco, Antonio Cano ${ }^{3}$, Miguel A García-Pérez ${ }^{1}$, María T Zarrabeitia ${ }^{4}$ and Jesús González-Macías \\ Department of Internal Medicine, Hospital U.M. Valdecilla-IFIMAV, University of Cantabria, RETICEF, Avda Valdecilla s/n, 39008 Santander, Spain, \\ ${ }^{1}$ Research Foundation, Hospital Clínico Universitario, Av. Blasco Ibañez, 17, E 46010 Valencia, Spain, ${ }^{2}$ Service of Orthopedic Surgery and Traumatology, \\ Hospital U.M. Valdecilla-IFIMAV, University of Cantabria, 39008 Santander, Spain, ${ }^{3}$ Department of Pediatrics, Obstetrics, and Gynecology, University of \\ Valencia, and University Hospital Dr., Peset University Hospital, Avda Gaspar Aguilar 90, 4017 Valencia, Spain and ${ }^{4}$ Unit of Legal Medicine, University of \\ Cantabria, C/Herrera Oria s/n 39011 Santander, Spain
}

(Correspondence should be addressed to J A Riancho; Email: rianchoj@unican.es)

\begin{abstract}
Objective: Genes explaining the susceptibility to osteoporosis have not been fully elucidated. Our objective was to explore the association of polymorphisms capturing common variations of the lipoprotein receptor-related protein ( $L R P) 5$ and 6 genes, encoding two Wnt receptors, with femoral neck bone mineral density (BMD) and osteoporotic fractures of the spine and the hip.

Design: Cross-sectional, case-control, and replication genetic association study.

Methods: Thirty-nine tagging and functional single nucleotide polymorphisms (SNPs) were analyzed in a group of 1043 postmenopausal women and 394 women with hip fractures. The results were replicated in a different group of 342 women.

Results: Three SNPs of the LRP6 gene were associated with BMD (nominal uncorrected $P$ values $<0.05)$ in the discovery cohort. One showed a significant association after multiple test correction; two of them were also associated in the replication cohort, with a combined standardized mean difference of $0.51(P=0.009)$ and $0.47(P<0.003)$ across rs11054704 and rs2302685 genotypes. In the discovery cohort, several LRP5 SNPs were associated with vertebral fractures (odds ratio (OR) $0.67 ; P=0.01$ ), with hip fractures (unadjusted ORs between 0.59 and $1.21 ; P=0.005-0.033$, but not significant after multiple test adjustment or age adjustment), and with height and the projected femoral neck area, but not with BMD. Transcripts of LRP5 and LRP6 were similarly abundant in bone samples.

Conclusions: In this study, we found common polymorphisms of LRP5 associated with osteoporotic fractures, and polymorphisms of the LRP6 gene associated with BMD, thus suggesting them as likely candidates to contribute to the explaination of the hereditary influence on osteoporosis.
\end{abstract}

European Journal of Endocrinology 164 123-131

\section{Introduction}

The Wnt family includes more than 15 proteins that have been shown to play an important role in organ development and the homeostasis of several adult tissues, including bone. Wnt ligands stimulate the differentiation of pluripotential precursors toward the osteoblastic lineage, and have an anabolic effect on bone. Intracellular signals transducing Wnt effects are complex and include several pathways; the best known among them is the so-called canonical pathway. It starts with the union of Wnt ligands to a membrane receptor complex constituted by a lipoprotein receptor-related peptide (LRP) and a frizzled protein. There are at least ten members of the frizzled family. There are also several LRPs, with positive or negative effects on Wnt signaling (1). The best-known members of the LRP family are LRP 5 and LRP6. The role of LRP 5 was emphasized by the discovery of some patients with either high or low bone mass phenotypes, caused by activating and loss-of-function mutations respectively of LRP5. Furthermore, several candidate gene studies and some multicenter large-scale and genome-wide association studies (GWASs) suggested that common LRP5 polymorphisms might influence bone mineral density (BMD) in the general population. Nevertheless, recent animal studies have raised some doubts about the direct role of LRP5 in bone (2). The role of LRP6 has not been studied extensively, but both LRP5 and LRP6 appear to be necessary for skeletal homeostasis (3, 4). Moreover, some investigators suggested that LRP6 polymorphisms influence BMD $(5,6)$, but the results were not confirmed in other studies $(7,8)$. Therefore, this is a controversial issue. Population differences and the particular polymorphisms included in those analyses may explain the discordant results. On the other hand, little is known 
about the relationship between LRP5/6 polymorphisms and hip fractures, which are the most devastating osteoporotic fractures. Therefore, the aim of this study was to use a gene-wide approach to explore the association of common polymorphisms of LRP5 and LRP6 genes with femoral neck BMD and osteoporotic fractures of the spine and the hip.

\section{Materials and methods}

\section{Subjects}

To study the association of genetic polymorphisms with BMD and vertebral fractures we performed a crosssectional study that included 1043 postmenopausal women over 50 years of age (age 51-90) living in Cantabria, a region in northern Spain with a population of 550000 . They included volunteers recruited by advertisements and women sent to our clinic because of osteoporosis concerns (Santander group) and women taking part in a population-based cohort study on the epidemiology of osteoporosis (Camargo cohort) (9). Both groups belonged to the same geographical region. Femoral neck BMD was measured by DXA using a Hologic QDR 4500 densitometer. The projected neck area in the DXA output was also analyzed. Since the densitometer uses a fixed length for femoral neck assessment, the projected area is a function of the neck diameter. The presence of vertebral fractures was defined as a loss of vertebral body height higher than $20 \%$ in lateral X-rays (available in 637 women), which were assessed by an experienced reader, prior to genotyping.

To study the association with hip fractures, we recruited a convenience sample of unselected patients admitted to a hospital because of a hip fracture, 60-90 years of age $(n=394)$. Those with fractures due to highimpact trauma (such as traffic accidents and falls from a height) were excluded. Control subjects $(n=529)$ included women from the Santander and Camargo

Table 1 Polymorphisms genotyped.

\begin{tabular}{|c|c|c|c|c|c|c|c|}
\hline Gene & Chrom & SNP & Position & $\begin{array}{l}\text { Minor } \\
\text { allele }\end{array}$ & $\begin{array}{l}\text { Major } \\
\text { allele }\end{array}$ & MAF & $\boldsymbol{P}$ (HWE) \\
\hline LRP5 & 11 & rs4988330 & 67837575 & $\mathrm{~T}$ & C & 0.08 & 0.43 \\
\hline$\angle R P 5$ & 11 & rs7116604 & 67841050 & $A$ & $\mathrm{G}$ & 0.13 & 0.83 \\
\hline$\angle R P 5$ & 11 & rs312014 & 67841538 & $\mathrm{C}$ & $\mathrm{G}$ & 0.39 & 0.35 \\
\hline$\angle R P 5$ & 11 & rs4988331 & 67841909 & $\mathrm{~T}$ & $\mathrm{C}$ & 0.08 & 0.65 \\
\hline LRP5 & 11 & rs4988300 & 67845407 & $\mathrm{G}$ & $\mathrm{T}$ & 0.48 & 0.81 \\
\hline LRP5 & 11 & rs312024 & 67851007 & $A$ & $\bar{G}$ & 0.31 & 0.62 \\
\hline$\angle R P 5$ & 11 & rs314779 & 67854402 & $\mathrm{G}$ & $\mathrm{T}$ & 0.31 & 0.35 \\
\hline$\angle R P 5$ & 11 & rs606989 & 67858576 & $\mathrm{~T}$ & $\mathrm{C}$ & 0.09 & 0.06 \\
\hline$\angle R P 5$ & 11 & rs314756 & 67868248 & $\mathrm{G}$ & $A$ & 0.07 & 1 \\
\hline LRP5 & 11 & rs3781596 & 67870578 & $\mathrm{C}$ & $G$ & 0.14 & 0.69 \\
\hline$\angle R P 5$ & 11 & rs643981 & 67872340 & $\mathrm{~T}$ & $\mathrm{C}$ & 0.44 & 0.88 \\
\hline$\angle R P 5$ & 11 & rs312786 & 67876553 & $\mathrm{~T}$ & $\mathrm{G}$ & 0.29 & 0.64 \\
\hline$\angle R P 5$ & 11 & rs312788 & 67878871 & $\mathrm{G}$ & $\mathrm{T}$ & 0.44 & 0.85 \\
\hline$\angle R P 5$ & 11 & rs11826287 & 67903237 & C & $\mathrm{T}$ & 0.19 & 0.26 \\
\hline$\angle R P 5$ & 11 & rs671191 & 67906557 & $\mathrm{C}$ & $\mathrm{T}$ & 0.38 & 0.02 \\
\hline LRP5 & 11 & rs4930573 & 67920032 & $\mathrm{G}$ & $\mathrm{C}$ & 0.32 & 0.87 \\
\hline LRP5 & 11 & rs587397 & 67923999 & $\mathrm{G}$ & C & 0.09 & 0.65 \\
\hline$\angle R P 5$ & 11 & rs4988321 & 67930765 & $A$ & $\mathrm{G}$ & 0.08 & 1 \\
\hline LRP5 & 11 & rs2306862 & 67934086 & $\mathrm{~T}$ & $\mathrm{C}$ & 0.20 & 0.55 \\
\hline$\angle R P 5$ & 11 & rs923346 & 67938951 & $\mathrm{C}$ & $\mathrm{T}$ & 0.20 & 0.60 \\
\hline LRP5 & 11 & rs1784235 & 67942076 & $\mathrm{C}$ & $\mathrm{T}$ & 0.28 & 0.76 \\
\hline LRP5 & 11 & rs556442 & 67949266 & $\mathrm{G}$ & $A$ & 0.39 & 0.47 \\
\hline$\angle R P 5$ & 11 & rs12417014 & 67957583 & $\mathrm{~T}$ & C & 0.10 & 0.13 \\
\hline LRP5 & 11 & rs3781579 & 67966294 & $G$ & $A$ & 0.16 & 0.09 \\
\hline LRP5 & 11 & rs632605 & 67972530 & $A$ & $\mathrm{G}$ & 0.07 & 1 \\
\hline$\angle R P 6$ & 12 & rs2075241 & 12182746 & C & $\mathrm{G}$ & 0.14 & 0.05 \\
\hline LRPG & 12 & rs718403 & 12188223 & $\mathrm{~T}$ & $\mathrm{C}$ & 0.24 & 0.43 \\
\hline$\angle R P G$ & 12 & rs11054704 & 12191036 & $A$ & $\mathrm{G}$ & 0.13 & 0.45 \\
\hline LRPG & 12 & rs2302685 & 12193165 & C & $\mathrm{T}$ & 0.16 & 0.53 \\
\hline LRPG & 12 & rs12833575 & 12216108 & $\mathrm{G}$ & $A$ & 0.06 & 0.68 \\
\hline LRPG & 12 & rs10082834 & 12225273 & $\mathrm{C}$ & $\mathrm{G}$ & 0.11 & 0.48 \\
\hline LRPG & 12 & rs17374170 & 12255678 & $\mathrm{C}$ & $\mathrm{T}$ & 0.08 & 1 \\
\hline LRPG & 12 & rs17302049 & 12256592 & $G$ & $A$ & 0.17 & 0.81 \\
\hline LRPG & 12 & rs1181334 & 12258855 & $\mathrm{~T}$ & $\mathrm{G}$ & 0.18 & 1 \\
\hline
\end{tabular}


groups within the same age range, but without osteoporotic fractures.

Women with present or past diseases (cancer, rheumatoid arthritis, malabsorption, severe systemic diseases, etc.) or treatments (corticosteroids, anticonvulsants, hormone replacement therapy, etc.), known to affect bone metabolism, or with non-Spanish ancestors were excluded. The study protocol was approved by the institutional committee of ethics in clinical research, and informed consent was obtained from the subjects or their representatives.

The results about genetic polymorphisms and BMD were replicated in a cohort of women attending a menopause clinic in Valencia, a region in eastern Spain. After applying similar exclusion criteria, the cohort included 342 Caucasian postmenopausal women aged 41-69 years. BMD was measured by DXA using either a Lunar or a Norland densitometer. The results from different densitometers were standardized as proposed by $\mathrm{Lu}$ et al. (10).

\section{Genotyping}

The Hapmap database was explored to identify single nucleotide polymorphisms (SNPs) of the LRP5 and LRP6 genes in the Caucasian population. Then, tagSNPs were selected using the algorithms available in Haploview with the 'aggressive tagging' option (11). Minor allele frequency (MAF) of 0.1 and $r^{2} 0.8$ were used as criteria. In addition, we included some SNPs with potential regulatory function as assessed by the bioinformatics suite Pupa $(12,13)$. Therefore, 31 SNPs of the LRP 5 gene and 11 of the LRP 6 gene were finally selected. DNA was isolated from peripheral blood or buccal swabs by using column-based commercial methods and quantified with the Qubit procedure (Invitrogen). Then alleles at each locus were analyzed by a mass-array Sequenom platform at the Centro Nacional de Genotipado (Santiago de Compostela, Spain). In a subsample of study participants, the rs3736228 polymorphism of the LRP5 gene was analyzed by using a Taqman assay (Applied Biosystems, Foster City, CA, USA). Polymorphisms associated with BMD in the discovery cohort were analyzed in the replication cohort by using the same procedure (mass-array) for genotyping at Unidad Central de Investigación (Facultad de Medicina, Valencia, Spain). Replicate samples were included to confirm the consistency of results.

\section{Gene expression}

Trabecular bone samples were obtained from the femoral heads of patients subjected to hip replacement because of severe osteoarthritis. RNA was isolated with Trizol (Invitrogen) and further purified by using a column adsorption procedure (Qiagen). Aliquots of RNA (250 ng) were reverse transcribed with the Superscript III kit (Invitrogen) and quantified by real-time PCR in an ABI7300 apparatus (Applied Biosystems), using specific primers and FAM-labeled probes for LRP5 and LRP6 (Taqman gene expression assays, Applied Biosystems). The results were then normalized to the expression of the housekeeping gene TATA box protein (TBP) and an universal reference RNA (Stratagene), by the $2^{-\Delta \Delta C_{\mathrm{t}}}$ method (14).

\section{Statistical analysis}

Haplotypic blocks were estimated by the Gabriel method and implemented in Haploview (11). The departure from the Hardy-Weinberg equilibrium was tested with PLINK software (15). The association of alleles with BMD was studied at the single-locus level, assuming additive and recessive models, with PLINK. The presence of population stratification was explored with STRUCTURE software, running a dataset with five markers located in different chromosomes (16). BMD results in different cohorts were combined by computing the Hedges' standardized weighted mean difference with MIX software $(17,18)$. The significance threshold after multiple test correction for each gene was estimated by

Table 2 Characteristics of study subjects (mean \pm s.D. or percentages).

\begin{tabular}{|c|c|c|c|c|}
\hline Cohort/phenotype & $\begin{array}{l}\text { Santander/BMD-vertebral } \\
\text { fractures }(n=608)\end{array}$ & $\begin{array}{l}\text { Camargo/BMD-vertebral } \\
\text { fractures }(n=435)\end{array}$ & $\begin{array}{l}\text { Hip fractures } \\
(n=394)\end{array}$ & $\begin{array}{l}\text { Valencia/BMD } \\
(n=342)\end{array}$ \\
\hline Age (years) & $69 \pm 7$ & $64 \pm 9$ & $80 \pm 7$ & $52 \pm 5$ \\
\hline Height (cm) & $155 \pm 6$ & $155 \pm 6$ & - & $158 \pm 6$ \\
\hline BMI $\left(\mathrm{kg} / \mathrm{m}^{2}\right)$ & $27.6 \pm 4.1$ & $28.9 \pm 4.8$ & - & $26.5 \pm 4.3$ \\
\hline Age at menopause (years) & $50 \pm 5$ & $49 \pm 5$ & - & $48 \pm 4$ \\
\hline Vertebral fractures $^{\mathrm{a}}(\%)$ & 36 & 8 & - & - \\
\hline Arm/forearm fractures (\%) & 11 & 8.4 & 16 & 9 \\
\hline $\operatorname{BMD}^{\mathrm{b}}\left(\mathrm{g} / \mathrm{cm}^{2}\right)$ & $0.671 \pm 0.112$ & $0.720 \pm 0.117$ & - & $0.804 \pm 0.115$ \\
\hline Smoking (\%) & 4 & 12 & 3 & 26 \\
\hline Calcium intake $^{c}$ (mg/day) & $659 \pm 397$ & $680 \pm 358$ & $620 \pm 376$ & - \\
\hline
\end{tabular}

${ }^{\text {aD }}$ Data from 637 women with X-rays.

${ }^{\mathrm{b}}$ Hologic DXA in Cantabria and standardized (Lunar or Norland) in Valencia.

${ }^{\mathrm{c}}$ From dairy products. 


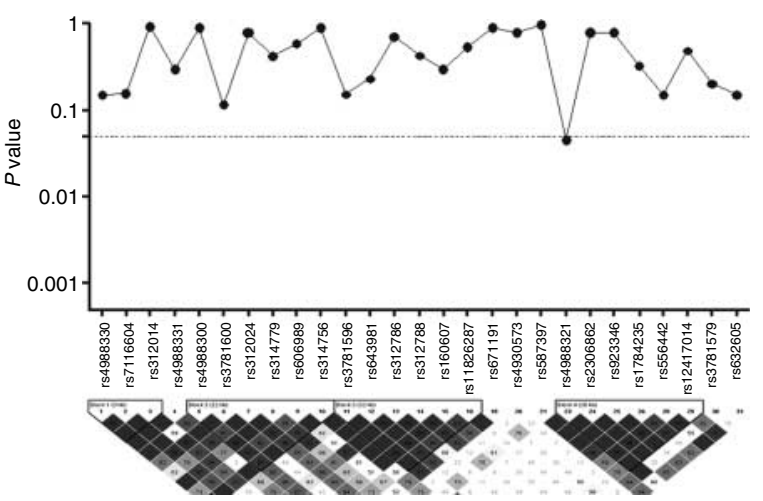

Figure 1 Association of LRP5 polymorphisms with femoral neck BMD. Nominal $P$ values under an age-adjusted recessive model.

considering the effective number of independent marker loci, using the single nucleotide spectral decomposition software (SNPSpD), developed by Nyholt (19). Uncorrected nominal $P$ values are shown, unless otherwise indicated. $P$ values $<0.05$ were considered as statistically significant. The study power (estimated with QUANTO software, available at http://hydra.usc.edu/ gxe/) was higher than $89 \%$ to find genetic effects explaining at least $1 \%$ of BMD variance. Power to detect a fracture odds ratio (OR) of 1.4 or higher was 80 and $54 \%$, for hip fractures and vertebral fractures respectively, assuming an additive model and an MAF of 0.2.

\section{Results}

\section{Bone mineral density}

Four SNPs of the LRP5 gene were excluded due to inaccurate separation or low calling rate. The genotyping rate in the remaining set (Table 1) was $97.4 \%$. The allelic frequencies were similar to those reported in other Caucasian populations and there was no evidence for departure from the Hardy-Weinberg equilibrium. Only one SNP was associated with a nominal $P$ value $<0.05(0.02$, well above the significance of 0.003 threshold after multiple test correction) (Table 1). No significant hidden population stratification was detected while running the STRUCTURE software. The characteristics of women included in the study are shown in Table 2.

The rs4988321 polymorphism of the LRP5 gene showed a marginal association with age-adjusted BMD $(P=0.0488$; Fig. 1$)$, which did not reach the multipletest-adjusted threshold of significance (estimated as $P=0.003)$. Three SNPs of the LRP6 gene were also associated with BMD: rs11054704 (additive $P=0.035$; recessive $P=0.016$ ), rs2302685 (additive $P=0.058$; recessive $P=0.0039$ ), and rs10845493 (additive $P=0.054$; recessive $P=0.036$; Fig. 2 ). Only the $P$ value for the rs2302685 polymorphism was below the multiple-test-adjusted threshold of significance (estimated as 0.006 for the LRP6 SNP set).

We selected those three SNPs for replication in a different cohort (Valencia). In this cohort, rs10845493 was not associated with BMD, but the association was replicated for rs $11054704(P=0.016$, additive model $)$ and almost reached statistical significance for rs2302685 ( $P=0.057$, additive model). The combined standardized weighted mean differences between women with opposite genotypes were 0.51 s.D. $(95 \%$ confidence interval $0.13-0.89$ ) and 0.47 S.D. (95\% confidence interval $0.16-0.77$ ) for rs11054704 and rs2302685 loci respectively (Table 3).

\section{Fractures}

The association of genetic polymorphisms with fractures was analyzed in 637 women with spine X-rays available (140 with osteoporotic vertebral fractures and 497 controls without fractures). Several polymorphisms of the LRP 5 gene tended to be associated with fractures, with nominal $P$ values $<0.05$, but they did not reach the multiple test threshold for significance (0.003). Loci rs312788 and rs160607 showed the most significant association. The age-adjusted OR was 0.67 in both the cases $(P=0.009$ and 0.01 respectively; Fig. 3$)$. The rs 3736228 polymorphism could not be included in the multiplex reaction along with other polymorphisms and was genotyped later in a single assay. It also tended to be associated with fractures in our population (OR $1.5 ; 95 \%$ confidence interval $1.1-2.2 ; P=0.025$ ).

Since LRP5 polymorphisms showed a trend for association with vertebral fractures, but not with BMD, we explored their relationship with body size. After excluding women with vertebral fractures

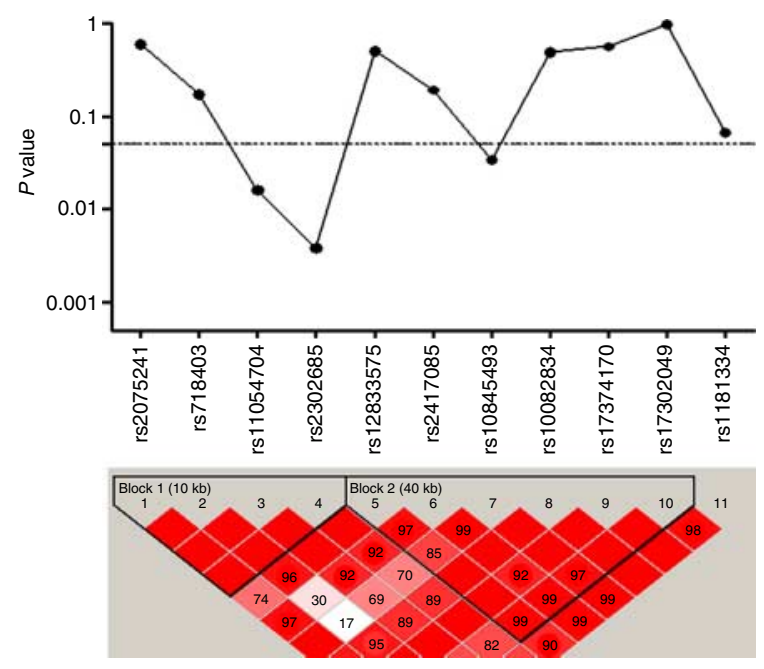

Figure 2 Association of $L R P 6$ polymorphisms with femoral neck BMD. Nominal $P$ values under an age-adjusted recessive model. Full colour version of this figure available via http://dx.doi.org/10. 1530/EJE-10-0582. 
Table 3 Association of LRP6 genotypes with BMD in the discovery and replication cohorts and combined estimate of effect. $P$ values for age-adjusted additive models in each cohort and standardized weighted mean difference (SWMD) between opposite homozygotes (in s.D. units).

\begin{tabular}{lllll}
\hline & \multicolumn{3}{c}{ Cohort } & \\
\cline { 2 - 3 } Locus & \multicolumn{1}{c}{ Cantabria } & \multicolumn{1}{c}{ Valencia } & Combined & SWMD \\
\hline rs11054704 & & & \\
AA & $0.626 \pm 0.180(19)$ & $0.757 \pm 0.103(8)$ & & \\
AG & $0.681 \pm 0.101(201)$ & $0.782 \pm 0.108(90)$ & & \\
GG & $0.688 \pm 0.117(782)$ & $0.813 \pm 0.116(222)$ & \multirow{2}{*}{0.009} & $0.51(\mathrm{GG}-\mathrm{AA})$ \\
$P$ value & 0.035 & 0.016 & & \\
& & & & \\
rs2302685 & $0.626 \pm 0.154(30)$ & $0.770 \pm 0.090(13)$ & & \\
CC & $0.687 \pm 0.104(254)$ & $0.788 \pm 0.112(91)$ & & \\
CT & $0.687 \pm 0.117(724)$ & $0.812 \pm 0.119(187)$ & & \\
TT & 0.058 & 0.057 & $<0.003$ & $0.47(\mathrm{TT}-\mathrm{CC})$ \\
$P$ value & & & \\
\hline
\end{tabular}

(which can cause a loss of height by themselves), several LRP5 polymorphisms were associated with height (uncorrected $P$ values 0.002-0.04; Fig. 3). Likewise, they were associated with the projected femoral neck area, as measured from the densitometer output, even after controlling for height $(P$ values $=0.0014-0.048$; Fig. 3 ).

Several LRP5 polymorphisms also tended to be associated with hip fractures (uncorrected $P$ values $<0.05$ ), including some found associated with vertebral fractures (rs4988300 and rs160607). However, the hip fracture group was somewhat older than the control group. After adjusting the results, introducing age as a covariate, similar ORs were observed, but with larger confidence intervals and were no longer statistically significant (Table 4).

SNPs of the LRP6 gene were not significantly associated with either vertebral or hip fractures.

The incomplete assessment of fractures in the Valencia cohort did not allow replicating fracture association data.

\section{Gene expression}

Gene transcripts were measured in 17 femoral bone samples of patients with osteoarthritis undergoing hip replacement surgery. Transcripts of LRP5 and LRP6 were similarly abundant: 1.5 (range $0.1-4.9$ ) and 1.2 (range 0.1-5.7) arbitrary units respectively (not significantly different).

\section{Discussion}

Rare cases of loss-of-function or gain-of-function mutations of LRP5 are associated with marked decreases or increases respectively of bone mass (20-23). Although the skeletal impact of common allelic variants is less clear, several polymorphisms of the LRP 5 gene have been associated with bone mass and fractures, in candidate gene studies $(6,24,25)$ and in some, but not all, GWASs $(26,27)$.
The nonsynonymous rs3736228 polymorphism has been the most widely studied SNP in candidate gene studies $(25,28)$ and was identified as a quantitative trait locus in the Rotterdam cohort GWAS. It showed a stronger association with spine BMD than with femoral neck BMD (26). In a meta-analysis including ten eligible studies with 16705 individuals, Tran et al. (25)

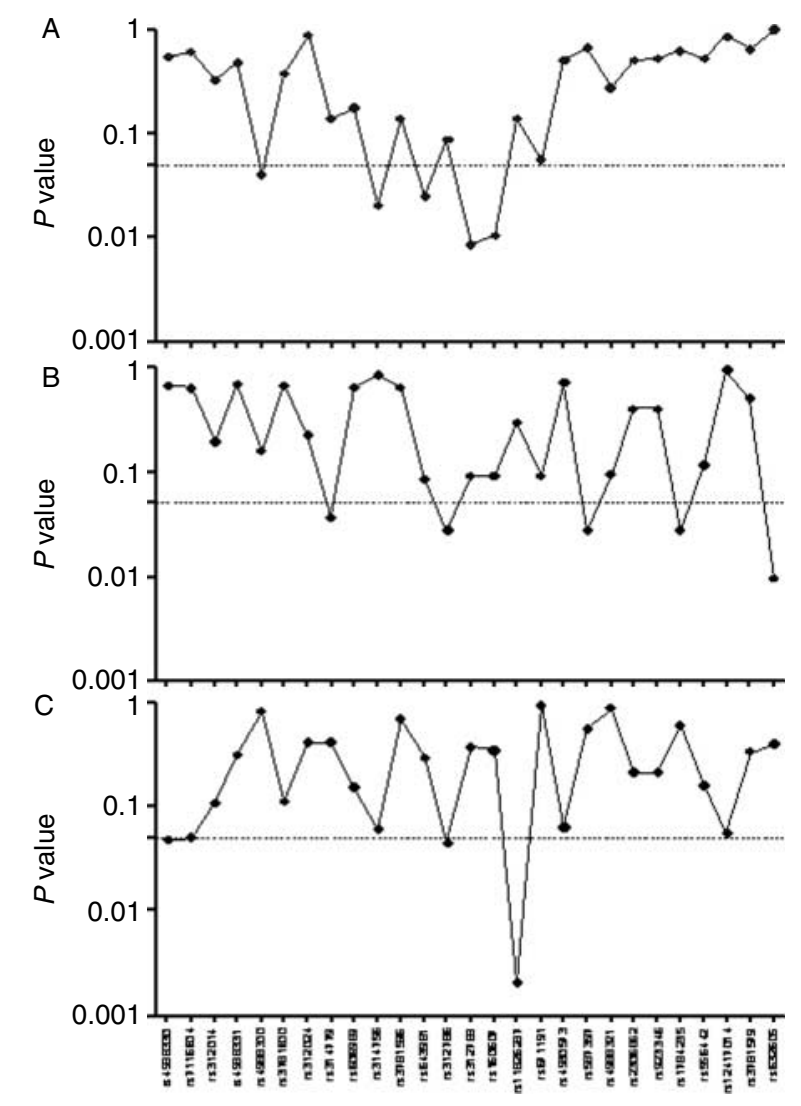

Figure 3 Association of $L R P 5$ polymorphisms with osteoporotic vertebral fractures $(A)$, femoral neck projected area $(B)$, and height (C). Nominal $P$ values under an additive age-adjusted model. 
Table 4 Association of LRP5 polymorphisms with hip fractures. Odds ratio (OR), limits of the 95\% confidence interval (L95 and U95), and $P$ values for additive models in the unadjusted and age-adjusted analyses.

\begin{tabular}{|c|c|c|c|c|c|c|c|c|c|}
\hline \multirow[b]{2}{*}{ SNP } & \multirow[b]{2}{*}{ Allele } & \multicolumn{4}{|c|}{ Undjusted analysis } & \multicolumn{4}{|c|}{ Age-adjusted analysis } \\
\hline & & OR & L95 & U95 & $P$ & OR & L95 & U95 & $P$ \\
\hline rs4988330 & $\mathrm{T}$ & 0.84 & 0.59 & 1.20 & 0.36 & 1.02 & 0.65 & 1.59 & 0.91 \\
\hline rs7116604 & $A$ & 0.90 & 0.67 & 1.19 & 0.47 & 1.15 & 0.80 & 1.64 & 0.43 \\
\hline rs312014 & C & 1.01 & 0.84 & 1.22 & 0.86 & 0.88 & 0.70 & 1.11 & 0.30 \\
\hline rs4988331 & $\mathrm{T}$ & 0.59 & 0.41 & 0.85 & 0.005 & 0.71 & 0.46 & 1.10 & 0.13 \\
\hline rs4988300 & $G$ & 1.25 & 1.04 & 1.50 & 0.017 & 1.12 & 0.89 & 1.40 & 0.32 \\
\hline rs3781600 & C & 0.98 & 0.73 & 1.31 & 0.91 & 1.14 & 0.79 & 1.64 & 0.46 \\
\hline rs312024 & A & 1.16 & 0.95 & 1.41 & 0.13 & 0.95 & 0.74 & 1.21 & 0.69 \\
\hline rs314779 & $\mathrm{G}$ & 0.90 & 0.74 & 1.10 & 0.31 & 0.90 & 0.70 & 1.14 & 0.40 \\
\hline rs606989 & $\mathrm{T}$ & 0.89 & 0.65 & 1.22 & 0.48 & 1.10 & 0.74 & 1.61 & 0.62 \\
\hline rs314756 & $\mathrm{G}$ & 0.87 & 0.60 & 1.26 & 0.49 & 0.81 & 0.52 & 1.27 & 0.36 \\
\hline rs3781596 & C & 0.74 & 0.56 & 0.97 & 0.033 & 0.93 & 0.66 & 1.31 & 0.70 \\
\hline rs643981 & $\mathrm{T}$ & 0.85 & 0.71 & 1.02 & 0.09 & 0.87 & 0.69 & 1.09 & 0.24 \\
\hline rs312786 & $\mathrm{T}$ & 0.93 & 0.76 & 1.14 & 0.52 & 0.83 & 0.65 & 1.07 & 0.16 \\
\hline rs312788 & $\mathrm{G}$ & 0.84 & 0.70 & 1.02 & 0.08 & 0.86 & 0.69 & 1.08 & 0.19 \\
\hline rs160607 & A & 0.81 & 0.67 & 0.97 & 0.025 & 0.83 & 0.67 & 1.04 & 0.12 \\
\hline rs11826287 & C & 0.96 & 0.76 & 1.22 & 0.78 & 0.90 & 0.67 & 1.19 & 0.47 \\
\hline rs671191 & C & 0.86 & 0.71 & 1.03 & 0.11 & 0.91 & 0.73 & 1.14 & 0.43 \\
\hline rs4930573 & G & 1.00 & 0.81 & 1.22 & 0.99 & 0.88 & 0.69 & 1.13 & 0.34 \\
\hline rs587397 & $\mathrm{G}$ & 0.84 & 0.60 & 1.17 & 0.31 & 0.81 & 0.53 & 1.22 & 0.31 \\
\hline rs4988321 & A & 1.10 & 0.78 & 1.56 & 0.55 & 1.12 & 0.73 & 1.71 & 0.58 \\
\hline rs2306862 & $\mathrm{T}$ & 1.01 & 0.80 & 1.28 & 0.88 & 0.93 & 0.69 & 1.24 & 0.62 \\
\hline rs923346 & C & 1.02 & 0.80 & 1.29 & 0.86 & 0.94 & 0.70 & 1.25 & 0.68 \\
\hline rs1784235 & C & 0.97 & 0.79 & 1.20 & 0.84 & 0.89 & 0.68 & 1.15 & 0.37 \\
\hline rs556442 & $\mathrm{G}$ & 0.94 & 0.77 & 1.14 & 0.54 & 0.99 & 0.77 & 1.26 & 0.95 \\
\hline rs12417014 & $\mathrm{T}$ & 0.88 & 0.64 & 1.21 & 0.44 & 0.99 & 0.66 & 1.47 & 0.97 \\
\hline rs3781579 & $\mathrm{G}$ & 0.97 & 0.76 & 1.25 & 0.86 & 0.96 & 0.70 & 1.31 & 0.81 \\
\hline rs632605 & A & 0.80 & 0.56 & 1.16 & 0.24 & 1.03 & 0.65 & 1.62 & 0.89 \\
\hline
\end{tabular}

Statistically significant values appear in boldface.

estimated that the difference in femoral neck BMD across rs3736288 genotypes was $0.011 \mathrm{~g} / \mathrm{cm}^{2}$, roughly equivalent to 0.1 S.D. Our study was not powered to detect such a small difference. The LRP5 polymorphism was also associated with fractures in the GWAS and in a large multicenter study (29). In this study, we confirmed the trend for association with vertebral fractures, but we were not able to confirm the association with BMD. Several factors may explain the differences between studies, including age and menopausal status of subjects. In fact, the association with fractures, but not with BMD, might suggest an effect of LRP 5 alleles on other factors influencing bone strength, such as bone tissue quality or bone geometry. In this study, some LRP5 polymorphisms were associated with body height and femoral neck size. This is in line with previously published results (30), and suggests that LRP5 may influence skeletal development and growth, and consequently the peak bone mass attained in early adulthood, as also suggested by studies showing an association of LRP5 polymorphisms with BMD in children and young adults (30-33). However, LRP5 SNPs associated with fractures did not coincide with those associated with height or femoral neck projected area. Therefore, further studies are needed to clarify the mechanism explaining the association of LRP 5 variants with fractures.
LRP5 and LRP6 are known to bind Wnt ligands, but their relative importance in bone tissue is unclear. Although several mutations of the LRP5 gene have been associated with abnormal human bone phenotypes (20, $21,23,34,35)$, only a pedigree with an LRP6 mutation causing metabolic syndrome, coronary heart disease, and osteoporosis has been reported (36). Studies with knockout mice suggest that both LRP5 and LRP6 are needed for the normal skeletal homeostasis $(3,4)$. In this study, we showed that LRP5 and LRP6 are expressed in similar amounts in human bone. However, unlike LRP5 polymorphisms, the association of genetic variants of LRP6 with bone mass has been rarely studied, and controversial results have been reported. van Meurs et al. (6) first published that the nonsynonymous rs2302685 polymorphism (Ile1062Val) of the LRP6 gene was associated with fragility fractures in men of the Rotterdam cohort. However, the results were not confirmed in a multicenter study (29) and no evidence for association with SNPs in the LRP6 region was found in a meta-analysis of data directly obtained or imputed from GWAS results (37). However, Sims et al. (5) reported an association of genetic variants of LRP6, and specifically rs11054704, with BMD in postmenopausal women. Trying to clarify the possible influence of LRP6 variants on bone mass, we performed a gene-wide analysis including tagging LRP6 SNPs in a defined 
population of postmenopausal women. There is no doubt that exploring the association of several SNPs with a phenotype inflate type I error (i.e. the possibility of false-positive associations). However, there is no general consensus about the best way to control it without compromising study power, particularly in hypothesis-driven candidate gene studies with several SNPs in linkage disequilibrium. In this study, we have used the method proposed by Nyholt (19), which takes into consideration the linkage between the genotyped loci. The replication in the independent cohorts may be the best way to confirm that the results are not just a chance finding. In this study, we have found an association of LRP6 SNPs with BMD, with some $P$ values below the multiple-test-adjusted threshold of significance. Furthermore, in the replication cohort we found a consistent association of two LRP6 polymorphisms with BMD. Thus, our results support the hypothesis that allelic variants of LRP6 are associated with BMD in postmenopausal women.

The nonsynonymous polymorphism rs2302865 is located in exon 14 of the LRP6 gene and causes an isoleucine/valine change. The rs11054704 polymorphism is located in intron 15 , just $2.1 \mathrm{~kb}$ downstream of rs2302865, and both belong to the same haplotypic block. The molecular mechanisms involved in the association of these SNPs with BMD remain to be elucidated. Nevertheless, according to the Fast SNP bioinformatic tool (http://fastsnp.ibms.sinica.edu.tw), the region including rs11054704 may act as an intronic enhancer and there may be allelic differences in the binding affinity for some transcription factors $(\mathrm{CEBP} / \beta, \quad \mathrm{CdxA})$. On the other hand, different rs2302685 alleles not only induce an amino acid change, which may impair the activity of LRP6, but they may also have splicing regulatory consequences. Therefore, considered together, these results strongly suggest that these polymorphisms, or other linked variants located in the same region of the LRP 6 gene, are indeed associated with individual differences in BMD. Our data suggest that in women with the least frequent homozygous genotype BMD is 0.5 s.D. lower than in those with the most frequent genotype. Such a difference is likely to have an important influence at the individual level, but it may be less important at the population level, because the risk genotype is present in only $2-3 \%$ of women. The explanation for the negative results in other studies is unclear $(7,29)$, but it might be related to differences in the populations studied or to cohort heterogeneity.

This study has several limitations. We estimated that the number of subjects included in Cantabria cohort resulted in $89 \%$ power to detect a genetic effect explaining $1 \%$ of the BMD variance. However, the sample size limited the statistical power to detect smaller effects, particularly in the replication cohort, which was relatively small and without enough numbers of fractures for replication (only clinical vertebral fractures were recorded because X-rays were not routinely obtained). We were not able to demonstrate a parallel association of LRP6 polymorphisms with fractures, which may be related to the small number of homozygotes for the risk allele and the moderate size of our fracture subgroup, which limited the power of the study when the minor allele frequencies were small. We do not have anthropometric data of patients with hip fractures. Therefore, we could not include some potentially important factors, such as body weight, as covariates.

In summary, our data is in line with previously published studies showing an association of LRP5 polymorphisms with osteoporotic fractures and strongly suggest that some genetic variants of LRP6 are associated with BMD in postmenopausal women, pointing toward both Wnt co-receptors as osteoporosis candidate genes.

\section{Declaration of interest}

The authors declare that there is no conflict of interest that could be perceived as prejudicing the impartiality of the research reported.

\section{Funding}

This study was supported by grants from Instituto de Salud Carlos IIIFondo de Investigaciones Sanitarias (PI 06/0034, 08/0183, PS09/00184, and PS09/01687).

\section{References}

1 Jeong YH, Sekiya M, HIrata M, Ye M, Yamagishi A, Lee SM, Kang MJ, Hosoda A, Fukumura T, Kim DH \& Saeki S. The low-density lipoprotein receptor-related protein 10 is a negative regulator of the canonical Wnt/beta-catenin signaling pathway. Biochemical and Biophysical Research Communications 2010392 495-499. (doi:10.1016/j.bbrc.2010.01.049)

2 Yadav VK, Ryu JH, Suda N, Tanaka KF, Gingrich JA, Schutz G, Glorieux FH, Chiang CY, Zajac JD, Insogna KL, Mann JJ, Hen R, Ducy P \& Karsenty G. Lrp5 controls bone formation by inhibiting serotonin synthesis in the duodenum. Cell 2008135 825-837. (doi:10.1016/j.cell.2008.09.059)

3 Holmen SL, Giambernardi TA, Zylstra CR, Buckner-Berghuis BD, Resau JH, Hess JF, Glatt V, Bouxsein ML, Ai M, Warman ML \& Williams BO. Decreased BMD and limb deformities in mice carrying mutations in both Lrp5 and Lrp6. Journal of Bone and Mineral Research 200419 2033-2040. (doi:10.1359/jbmr. 040907)

4 Zylstra CR, Wan C, VanKoevering KK, Sanders AK, Lindvall C, Clemens TL \& Williams BO. Gene targeting approaches in mice: assessing the roles of LRP5 and LRP6 in osteoblasts. Journal of Musculoskeletal \& Neuronal Interactions 20088 291-293.

5 Sims AM, Shephard N, Carter K, Doan T, Dowling A, Duncan EL, Eisman J, Jones G, Nicholson G, Prince R, Seeman E, Thomas G, Wass JA \& Brown MA. Genetic analyses in a sample of individuals with high or low bone density demonstrates association with multiple Wnt pathway genes. Journal of Bone and Mineral Research 200823 499-506. (doi:10.1359/jbmr.071113)

6 van Meurs JB, Rivadeneira F, Jhamai M, Hugens W, Hofman A, van Leeuwen JP, Pols HA \& Uitterlinden AG. Common genetic variation of the low-density lipoprotein receptor-related protein 5 and 6 genes determines fracture risk in elderly white men. Journal of Bone and Mineral Research 200621 141-150. (doi:10.1359/JBMR. 050904) 
7 Mencej-Bedrac S, Prezelj J, Kocjan T, Komadina R \& Marc J. Analysis of association of LRP5, LRP6, SOST, DKK1, and CTNNB1 genes with bone mineral density in a Slovenian population. Calcified Tissue International 200985 501-506. (doi:10.1007/ s00223-009-9306-y)

8 Yerges LM, Klei L, Cauley JA, Roeder K, Kammerer CM, Ensrud KE, Nestlerode CS, Lewis C, Lang TF, Barrett-Connor E, Moffett SP, Hoffman AR, Ferrell RE, Orwoll ES \& Zmuda JM. Candidate gene analysis of femoral neck trabecular and cortical volumetric bone mineral density in older men. Journal of Bone and Mineral Research 201025 330-338. (doi:10.1359/jbmr.090729)

9 Olmos JM, Hernandez JL, Martinez J, Pariente E, Llorca J \& Gonzalez-Macias J. Bone turnover markers in Spanish adult men: the Camargo Cohort Study. Clinica Chimica Acta 2010411 19-20. (doi:10.1016/j.cca.2010.06.010)

$10 \mathrm{Lu} \mathrm{Y,} \mathrm{Fuerst} \mathrm{T,} \mathrm{Hui} \mathrm{S} \mathrm{\&} \mathrm{Genant} \mathrm{HK.} \mathrm{Standardization} \mathrm{of} \mathrm{bone}$ mineral density at femoral neck, trochanter and Ward's triangle. Osteoporosis International $2001 \mathbf{1 2}$ 438-444. (doi:10.1007/ s001980170087)

11 Barrett JC, Fry B, Maller J \& Daly MJ. Haploview: analysis and visualization of $\mathrm{LD}$ and haplotype maps. Bioinformatics 200521 263-265. (doi:10.1093/bioinformatics/bth457)

12 Conde L, Vaquerizas JM, Dopazo H, Arbiza L, Reumers J, Rousseau F, Schymkowitz J \& Dopazo J. PupaSuite: finding functional single nucleotide polymorphisms for large-scale genotyping purposes. Nucleic Acids Research 200634 W621-W625. (doi:10.1093/nar/gkl071)

13 Reumers J, Conde L, Medina I, Maurer-Stroh S, Van Durme J, Dopazo J, Rousseau F \& Schymkowitz J. Joint annotation of coding and non-coding single nucleotide polymorphisms and mutations in the SNPeffect and PupaSuite databases. Nucleic Acids Research 200836 D825-D829. (doi:10.1093/nar/gkm979)

14 Livak KJ \& Schmittgen TD. Analysis of relative gene expression data using real-time quantitative PCR and the $2(-$ Delta Delta C(T)) method. Methods 200125 402-408. (doi:10.1006/meth. 2001.1262)

15 Purcell S, Neale B, Todd-Brown K, Thomas L, Ferreira MA, Bender D, Maller J, Sklar P, de Bakker PI, Daly MJ \& Sham PC. PLINK: a tool set for whole-genome association and populationbased linkage analyses. American Journal of Human Genetics 2007 81 559-575. (doi:10.1086/519795)

16 Pritchard JK, Stephens M \& Donnelly P. Inference of population structure using multilocus genotype data. Genetics 2000155 945-959.

17 Petitti DB. Meta-analysis, Decision Analysis and Cost-effectiveness Analysis. Methods for Quantitative Synthesis in Medicine New York: Oxford University Press, 2000.

18 Bax L, Yu LM, Ikeda N, Tsuruta H \& Moons KG. Development and validation of MIX: comprehensive free software for meta-analysis of causal research data. BMC Medical Research Methodology 2006 6 50. (doi:10.1186/1471-2288-6-50)

19 Nyholt DR. A simple correction for multiple testing for singlenucleotide polymorphisms in linkage disequilibrium with each other. American Journal of Human Genetics 2004 74 765-769. (doi:10.1086/383251)

20 Little RD, Carulli JP, Del Mastro RG, Dupuis J, Osborne M, Folz C, Manning SP, Swain PM, Zhao SC, Eustace B, Lappe MM, Spitzer L, Zweier S, Braunschweiger K, Benchekroun Y, Hu X, Adair R, Chee L, FitzGerald MG, Tulig C, Caruso A, Tzellas N, Bawa A, Franklin B, McGuire S, Nogues X, Gong G, Allen KM, Anisowicz A, Morales AJ, Lomedico PT, Recker SM, Van Eerdewegh P, Recker RR \& Johnson ML. A mutation in the LDL receptor-related protein 5 gene results in the autosomal dominant high-bone-mass trait. American Journal of Human Genetics 2002 70 11-19. (doi:10. $1086 / 338450)$

21 Balemans W \& Van Hul W. The genetics of low-density lipoprotein receptor-related protein 5 in bone: a story of extremes. Endocrinology 2007148 2622-2629. (doi:10.1210/en.20061352)

22 Gong Y, Slee RB, Fukai N, Rawadi G, Roman-Roman S, Reginato AM, Wang H, Cundy T, Glorieux FH, Lev D,
Zacharin M, Oexle K, Marcelino J, Suwairi W, Heeger S, Sabatakos G, Apte S, Adkins WN, Allgrove J, Arslan-Kirchner M, Batch JA, Beighton P, Black GC, Boles RG, Boon LM, Borrone C, Brunner HG, Carle GF, Dallapiccola B, de Paepe A, Floege B, Halfhide ML, Hall B, Hennekam RC, Hirose T, Jans A, Juppner H, Kim CA, Keppler-Noreuil K, Kohlschuetter A, Lacombe D, Lambert M, Lemyre E, Letteboer T, Peltonen L, Ramesar RS, Romanengo M, Somer H, Steichen-Gersdorf E, Steinmann B, Sullivan B, Superti-Furga A, Swoboda W, van den Boogaard MJ, Van Hul W, Vikkula M, Votruba M, Zabel B, Garcia T, Baron R, Olsen BR \& Warman ML. LDL receptor-related protein 5 (LRP5) affects bone accrual and eye development. Cell 2001 107 513-523. (doi:10.1016/S0092-8674(01)00571-2)

23 Narumi S, Numakura C, Shiihara T, Seiwa C, Nozaki Y, Yamagata T, Momoi MY, Watanabe Y, Yoshino M, Matsuishi T, Nishi E, Kawame H, Akahane T, Nishimura G, Emi M \& Hasegawa T. Various types of LRP5 mutations in four patients with osteoporosis-pseudoglioma syndrome: identification of a 7.2$\mathrm{kb}$ microdeletion using oligonucleotide tiling microarray. American Journal of Medical Genetics 2010 152A 133-140. (doi:10.1002/ ajmg.a.33177)

24 Agueda L, Bustamante M, Jurado S, Garcia-Giralt N, Ciria M, Salo G, Carreras R, Nogues X, Mellibovsky L, Diez-Perez A, Grinberg D \& Balcells S. A haplotype-based analysis of the LRP5 gene in relation to osteoporosis phenotypes in Spanish postmenopausal women. Journal of Bone and Mineral Research 200823 1954-1963. (doi:10.1359/jbmr.080806)

25 Tran BN, Nguyen ND, Eisman JA \& Nguyen TV. Association between LRP5 polymorphism and bone mineral density: a Bayesian meta-analysis. BMC Medical Genetics 2008955. (doi:10.1186/1471-2350-9-55)

26 Richards JB, Rivadeneira F, Inouye M, Pastinen TM, Soranzo N, Wilson SG, Andrew T, Falchi M, Gwilliam R, Ahmadi KR, Valdes AM, Arp P, Whittaker P, Verlaan DJ, Jhamai M, Kumanduri V, Moorhouse M, van Meurs JB, Hofman A, Pols HA, Hart D, Zhai G, Kato BS, Mullin BH, Zhang F, Deloukas P, Uitterlinden AG \& Spector TD. Bone mineral density, osteoporosis, and osteoporotic fractures: a genome-wide association study. Lancet 2008371 1505-1512. (doi:10.1016/S0140-6736(08)60599-1)

27 Styrkarsdottir U, Halldorsson BV, Gretarsdottir S, Gudbjartsson DF, Walters GB, Ingvarsson T, Jonsdottir T, Saemundsdottir J, Center JR, Nguyen TV, Bagger Y, Gulcher JR, Eisman JA, Christiansen C, Sigurdsson G, Kong A, Thorsteinsdottir U \& Stefansson K. Multiple genetic loci for bone mineral density and fractures. New England Journal of Medicine 2008358 2355-2365. (doi:10.1056/NEJMoa0801197)

28 Lee YH, Woo JH, Choi SJ, Ji JD \& Song GG. Association between the A1330V polymorphism of the low-density lipoprotein receptorrelated protein 5 gene and bone mineral density: a meta-analysis. Rheumatology International 200929 539-544. (doi:10.1007/ s00296-008-0745-y)

29 van Meurs JB, Trikalinos TA, Ralston SH, Balcells S, Brandi ML, Brixen K, Kiel DP, Langdahl BL, Lips P, Ljunggren O, Lorenc R, Obermayer-Pietsch B, Ohlsson C, Pettersson U, Reid DM, Rousseau F, Scollen S, Van Hul W, Agueda L, Akesson K, Benevolenskaya LI, Ferrari SL, Hallmans G, Hofman A, Husted LB, Kruk M, Kaptoge S, Karasik D, Karlsson MK, Lorentzon M, Masi L, McGuigan FE, Mellstrom D, Mosekilde L, Nogues X, Pols HA, Reeve J, Renner W, Rivadeneira F, van Schoor NM, Weber K, Ioannidis JP \& Uitterlinden AG. Large-scale analysis of association between LRP5 and LRP6 variants and osteoporosis. Journal of the American Medical Association 2008299 1277-1290. (doi:10.1001/jama.299.11.1277)

30 Ferrari SL, Deutsch S, Choudhury U, Chevalley T, Bonjour JP, Dermitzakis ET, Rizzoli R \& Antonarakis SE. Polymorphisms in the low-density lipoprotein receptor-related protein 5 (LRP5) gene are associated with variation in vertebral bone mass, vertebral bone size, and stature in whites. American Journal of Human Genetics 200474 866-875. (doi:10.1086/420771) 
31 Giroux S, Elfassihi L, Cardinal G, Laflamme N \& Rousseau F. LRP5 coding polymorphisms influence the variation of peak bone mass in a normal population of French-Canadian women. Bone 2007 40 1299-1307. (doi:10.1016/j.bone.2007.01.004)

32 Brixen K, Beckers S, Peeters A, Piters E, Balemans W, Nielsen TL, Wraae K, Bathum L, Brasen C, Hagen C, Andersen M, Van Hul W \& Abrahamsen B. Polymorphisms in the low-density lipoprotein receptor-related protein 5 (LRP5) gene are associated with peak bone mass in non-sedentary men: results from the Odense androgen study. Calcified Tissue International 200781 421-429. (doi:10.1007/s00223-007-9088-z)

33 Koay MA, Tobias JH, Leary SD, Steer CD, Vilarino-Guell C \& Brown MA. The effect of LRP5 polymorphisms on bone mineral density is apparent in childhood. Calcified Tissue International 2007 81 1-9. (doi:10.1007/s00223-007-9024-2)

34 Chung BD, Kayserili H, Ai M, Freudenberg J, Uzumcu A, Uyguner O, Bartels CF, Honing S, Ramirez A, Hanisch FG, Nurnberg G, Nurnberg P, Warman ML, Wollnik B, Kubisch C \& Netzer C. A mutation in the signal sequence of LRP5 in a family with an osteoporosis-pseudoglioma syndrome (OPPG)-like phenotype indicates a novel disease mechanism for trinucleotide repeats. Human Mutation 200930 641-648. (doi:10.1002/ humu.20916)
35 Streeten EA, McBride D, Puffenberger E, Hoffman ME, Pollin TI, Donnelly P, Sack P \& Morton H. Osteoporosis-pseudoglioma syndrome: description of 9 new cases and beneficial response to bisphosphonates. Bone 200843 584-590. (doi:10.1016/j.bone. 2008.04.020)

36 Mani A, Radhakrishnan J, Wang H, Mani A, Mani MA, NelsonWilliams C, Carew KS, Mane S, Najmabadi H, Wu D \& Lifton RP. LRP6 mutation in a family with early coronary disease and metabolic risk factors. Science 2007315 1278-1282. (doi:10. 1126/science.1136370)

37 Richards JB, Kavvoura FK, Rivadeneira F, Styrkarsdottir U, Estrada K, Halldorsson BV, Hsu YH, Zillikens MC, Wilson SG, Mullin BH, Amin N, Aulchenko YS, Cupples LA, Deloukas P, Demissie S, Hofman A, Kong A, Karasik D, van Meurs JB, Oostra BA, Pols HA, Sigurdsson G, Thorsteinsdottir U, Soranzo N, Williams FM, Zhou Y, Ralston SH, Thorleifsson G, Van Duijn CM, Kiel DP, Stefansson K, Uitterlinden AG, Ioannidis JP \& Spector TD. Collaborative meta-analysis: associations of 150 candidate genes with osteoporosis and osteoporotic fracture. Annals of Internal Medicine 2009151 528-537.

Received 2 October 2010

Accepted 6 October 2010 